\title{
IMPROVING BUSINESS ENGLISH AND MANAGEMENT STUDENTS' READING COMPREHENSION THROUGH STRUCTURAL ANALYSIS
}

\author{
Fariska Wulandari, \\ Business English and Management Tonggak Equator Polytechnic \\ RiskaDiandra0212@gmail.com
}

\begin{abstract}
This research was purposed to find out how the use of structural analysis improve the reading comprehension of $\mathrm{E}$ class second semester students of Business English and Management Major Tonggak Equator Polytechnic in academic year 2017-2018 and how significant does the use of structural analysis improve the reading comprehension of $\mathrm{E}$ class second semester students of Business English and Management Major Tonggak Equator Polytechnic in academic year 2017-2018. This research was classroom action research which was set out in two cycles, they are first and second cycle. The subject of this research was E class second semester students of Business English and Management Concentration of Tonggak Equator Polytechnic in academic year 2017-2018. Field note and test were used in collecting the data. The test consists of pre-test and progress-test. The data of the students pre-test and progresstest score were analyzed by using mean score and the data of the observation by using field note was analyzed descriptively. The finding of the research was structural analysis positively improved the reading comprehension of E class second semester students of Business English and Management Major Tonggak Equator Polytechnic in academic year 2017-2018 within two cycles, and the significance of the use of structural analysis in improving the reading comprehension of E class second semester students of Business English and Management Major Tonggak Equator Polytechnic in academic year 2017-2018 could be seen based on the test given they were 64 for the pre-test, 71.6 for the first progress-test and 83.4 for the second progresstest, and from the field note, that the students looked tired, sleepy, looked for answer from student beside them and could not finish the test by the time given by the researcher in the first cycle but have significant progress in the second cycle that the students looked more relax in doing the test and could finish the test by the time given by the researcher.

Keywords: reading comprehension, structural analysis, classroom action research.
\end{abstract}

\begin{abstract}
Abstrak
Penelitian ini bertujuan untuk mengetahui bagaimana structural analysis meningkatkan pemahaman membaca mahasiswa Politeknik Tonggak Equator Konsentasi Business English and Management semester II kelas E tahun ajaran 2017-2018 dan seberapa signifikan structural analysis meningkatkan pemahaman membaca mahasiswa Politeknik Tonggak Equator Konsentasi Business English and Management semester II kelas E tahun ajaran 2017-2018. Penelitian ini merupakan penelitian tindakan kelas yang dilakukan dalam dua siklus yaitu siklus pertama dan siklus kedua. Subjek dalam penelitian ini adalah mahasiswa Politeknik Tonggak Equator Konsentrasi Business English and Management semester II kelas E tahun ajaran 20172018. Pengumpulan data dalam penelitian ini menggunakan catatan lapangan dan tes. Tes yang diberikan terdiri dari pre-test dan progress-test. Nilai pre-test dan progress-test dianalisis menggunakan nilai rata-rata sedangkan data observasi menggunakan catatan lapangan dianalisis secara deskriptif. Temuan dari penelitian ini adalah structural analysis secara positif meningkatkan pemahaman membaca mahasiswa Politeknik Tonggak Equator konsentrasi Business English and Management semester II kelas E tahun ajaran 2017-2018 dalam dua siklus, dan signifikansi penggunaan structural analysis dalam meningkatkan pemahaman membaca mahasiswa Politeknik Tonggak Equator konsentrasi Business English and Management semester II kelas E tahun ajaran 2017-2018 dapat dilihat berdasarkan hasil tes yang diberikan yaitu 64 untuk nilai rata-rata pre-test, 71,6 untuk nilai rata-rata progress-test
\end{abstract}


satu dan 83,4 untuk nilai rata-rata progress-test kedua, serta dari hasil catatan lapangan dimana mahasiswa terlihat lelah, mengantuk dan mencari jawaban dengan bertanya teman di sebelahnya dan tidak dapat menyelesaikan tes sesuai dengan waktu yang telah diberikan peneliti di siklus pertama namun memiliki progress yang signifikan di siklus kedua dimana mahasiswa terlihat lebih santai dalam mengerjakan tes dan dapat menyelesaikan tes sesuai dengan waktu yang diberikan oleh peneliti.

Kata kunci: pemahaman membaca, analisis structural, penelitian tindakan kelas.

\section{INTRODUCTION}

Reading is one of language skills that must be learnt by students since it is a receptive skill that will affects the development of productive skills, speaking and writing. For university students, reading is essential since they have to read their compulsory books, journals or other materials related to their lesson. For students of English Language Department, reading is one of crucial subject because the better their reading ability the better their writing and speaking will be.

Table 1.1 Reading II Mid-term Test Score of Students

\begin{tabular}{clcc}
\hline No & $\begin{array}{c}\text { Students } \\
\text { Name }\end{array}$ & $\begin{array}{c}\text { Reading II Mid-term Test } \\
\text { Score }\end{array}$ & $\begin{array}{c}\text { Speaking II Mid-term } \\
\text { Test Score }\end{array}$ \\
\hline 1 & AMD & 42.5 & 65 \\
\hline 2 & A & 20 & 57 \\
\hline 3 & AM & 50 & 75 \\
\hline 4 & CC & 80 & 90 \\
\hline 5 & DG & 62.5 & 70 \\
\hline 6 & ES & 35 & 65 \\
\hline 7 & E & 22.5 & 70 \\
\hline 8 & EA & 50 & 70 \\
\hline 9 & F & 62.5 & 72 \\
\hline 10 & F & 40 & 75 \\
\hline 11 & F & 52.5 & 76 \\
\hline 12 & FDMN & 47.5 & 63 \\
\hline 13 & FH & 37.5 & 84 \\
\hline 14 & IO & 75 & 75 \\
\hline 15 & IJ & 57.5 & 69 \\
\hline 16 & JC & 78 & 87 \\
\hline 17 & K & 52.5 & 73 \\
\hline 18 & LJA & 67.5 & 66 \\
\hline 19 & MID & 72.5 & 84 \\
\hline 20 & R & 62.5 & 83 \\
\hline 21 & RA & 87.5 & 87 \\
\hline 22 & R & 57.5 & 65 \\
\hline & & & \\
\hline
\end{tabular}




\begin{tabular}{llcc}
\hline 23 & RS & 52.5 & 63 \\
\hline 24 & SF & 63 & 79 \\
\hline 25 & SM & 47.5 & 79 \\
\hline 26 & S & 52.5 & 75 \\
\hline 27 & V & 80 & 81 \\
\hline 28 & VS & 77.5 & 93 \\
\hline 29 & WR & 27.5 & 50 \\
\hline 30 & YML & 12.5 & 66 \\
\hline 31 & YDS & 72.5 & 75 \\
\hline \multicolumn{2}{r}{ Mean Score } & 54.7 & 73.6 \\
\hline
\end{tabular}

Source: BAAK Politeknik Tonggak Equator

Based on table 1.1, it can be seen that the students' mid-term test score of Reading II and Speaking II was not really good since the mean score of Reading II mid-term test was only 54.7 and the mean score of Speaking II mid-term test was only 73.6

Beside the low score of the students' mid-term test, the researcher also found some problems on students reading comprehension based on her observation in Tonggak Equator Polytechnic, Business English and Management Major class E second semester students. The problems are the students hard to find the meaning of the words, the students cannot find the general and specific information of the text, and the students do not understand the passage. Therefore, the researcher consider it is important for her to find and teach strategy in order to help the students improve their reading ability.

Structural analysis is an approach that help the students to find the meaning of the word by analyzing the parts of the word and how the parts are combined. These word parts are usually in the form of prefix, suffix, root, and compound. For example, the word of microbiology. If in the word of microbiology, the students do not know the meaning but they know that micro means "small," bio means "life," and logy means "study of," then the students will know that microbiology means "the study of small life." This approach when used by the students will let them to get a better understanding of words. Therefore, the researcher interested to conduct a research entitled Improving Business English and Management Students' Reading Comprehension through Structural Analysis. 
Based on the problems found by the researcher in the classroom, the researcher formulated the problem formulation as follow: (1) How the use of structural analysis improve the reading comprehension of E class second semester students of Business English and Management Major Tonggak Equator Polytechnic in academic year 2017-2018; and (2) How significant does the use of structural analysis improve the reading comprehension of E class second semester students of Business English and Management Concentration Tonggak Equator Polytechnic in academic year 2017-2018.

Two purposes of this research were to find out (1) how the use of structural analysis improves the reading comprehension of E class second semester students of Business English and Management Major Tonggak Equator Polytechnic in academic year 2017-2018; and (2) How significant the use of structural analysis improves the reading comprehension of $\mathrm{E}$ class second semester students of Business English and Management Major Tonggak Equator Polytechnic in academic year 2017-2018.

Silberstein (1994:120) states that "reading is an active process." Describing reading as an active process means that when students read and contemplate the text or passage, they preview the text by activating their background knowledge, making predictions about the content, making connection to self, text, and world. According to Patel and Jain (2008:113) "reading is the most important activity in language class." Reading is a source of information, knowledge and pleasurable.

Moreover, Linge (2000) states "reading comprehension is the ability to think words together into sentences and to understand the idea that the author is trying to convey in those sentences. Therefore, reading comprehension is process of developing thinking. When readers read, they carry on a conversation with the text. They respond the text with happiness, sadness, amazement, wonder, ignorance, etc.

For Indonesian, English is a foreign language. Teaching reading comprehension to English Foreign Language (EFL) learners is not an easy job such Nuttal (1982:21) states "the aim of teaching reading comprehension is to develop the students' ability to extract the message from the content. In teaching reading 
comprehension, the teachers are trying to put something in the students' mind to take the information by them." In teaching reading comprehension, the role of teacher is to make the students have their own ability to read and understand the reading text.

Obviously, checking dictionary is not allowed in the examination so the students tend to get difficulty in words they do not understand. Therefore, they need strategy to overcome it and one of them is structural analysis. According to Hancock (1987:17), "structural analysis is analyzing a word according to the parts of the word and how the parts are combined. These word parts are usually in the form of prefixes, suffixes, roots and compounds. In order to utilize this approach effectively, the learners must become familiar with some common roots, prefixes, and suffixes." Therefore, the learners must be familiar with roots, prefixes, and suffixes in order to use this strategy

"A prefix is a word part added before the word to change or modify the meaning. Some prefixes have more than one meaning." (Hancock, 1987:20). Therefore, the readers should always consider the context of the word when determining the meaning. Meanwhile, "a suffix is a word part added at the end of a word. A suffix can modify the meaning of a word and/or change the part of speech of the word." (Hancock, 1987:22)

The action hypothesis of this research is structural analysis will significantly improve the reading comprehension of E class second semester students of Business English and Management Tonggak Equator Polytechnic in academic year 20172018. The result of this research will give a lot of advantages, they are: (1) improve the students' reading comprehension; and (2) the finding of this research will give additional reference for teacher, lecturer and researcher who want to conduct a research related to improving reading comprehension.

\section{METHOD}

This research is classroom action research which was set out in two cycles. In doing this research, the researcher used action research design introduced by Kemmis and McTaggart (1988) in Burn (2010:9) which is set out in the figure below. 


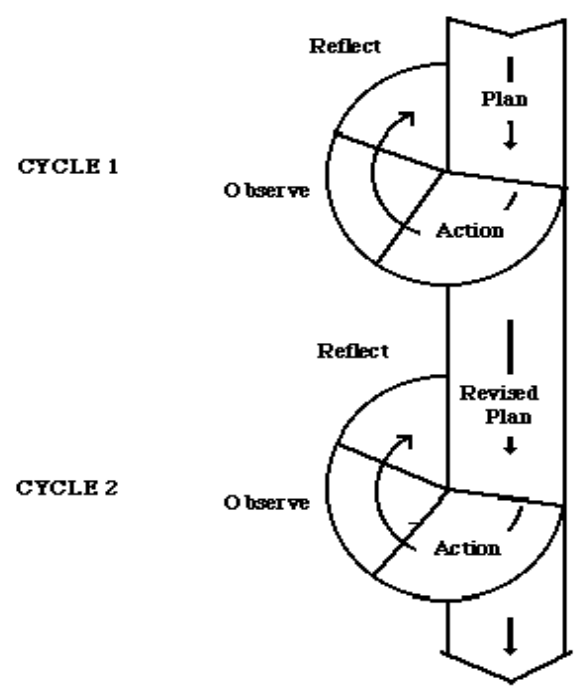

Figure1 Cyclical Action Research Model based on Kemmis and McTaggart

In the stage of planning, researcher planned the teaching-learning activities to overcome the students' reading problem. The plan consisted of lesson plan, instruments of data collecting such as field note and test (pre-test and progress-test). In the stage of acting, researcher applied the plans that she has made. In the stage of observing, the researcher observed the learning process and wrote it in the field note. In the stage of reflecting, the researcher reflected the action that has been done, tried to find out the solution of the problem happened and avoid the same problem happen in the next cycle.

There were some procedures were done in this research, they were big cycle and small cycle. Big cycle consisted of 6 meetings in which the researcher applied structural analysis in her teaching-learning process. Big cycle consisted of cycle 1 cycle 2 in which each cycle consisted of three meetings. Small cycle consists of a meeting which last about 150 minutes.

This research was done in Tonggak Equator Polytechnic. The subject of this research was E class second semester students of Business English and Management Concentration of Tonggak Equator Polytechnic in academic year 2017-2018. Field note and test were used by the researcher in gathering the data. Field note was used to record what happened in the classroom. The test consisted of pre-test and progress-test. Pre-test was used to know the students' reading 
comprehension before given the treatment by the researcher and progress-test was used to know the progress or improvement of the students' reading comprehension.

The researcher analyzed the result of the field note descriptively and the test of students' reading comprehension which consisted of progress-test 1 and progress-test 2 by using mean score in the following formula:

$$
M=\frac{\sum X}{N}
$$

Note:

$$
\begin{array}{ll}
\mathrm{M} & =\text { the students' mean score } \\
\sum X & =\text { the sum of students' score } \\
\mathrm{N} & =\text { the number of students }
\end{array}
$$

\begin{tabular}{|c|c|c|}
\hline Numeric Scores & Relative Scores & Marking Quality \\
\hline $85-100$ & $\mathrm{~A}$ & Very good \\
\hline $81-84$ & A- & Almost very good \\
\hline $77-80$ & $\mathrm{~B}+$ & Better \\
\hline $73-76$ & $\mathrm{~B}$ & Good \\
\hline $69-72$ & B- & Almost good \\
\hline $65-68$ & $\mathrm{C}+$ & More than fair \\
\hline $60-64$ & $\mathrm{C}$ & Fair \\
\hline $45-59$ & $\mathrm{D}$ & Less \\
\hline $0-44$ & $E$ & $\mathrm{Bad}$ \\
\hline
\end{tabular}

The result will be categorized as follow:

Table 1 Categorize of Score

Source: Buku Pedoman Politeknik Tonggak Equator (2017)

\section{FINDING AND DISCUSSION}

There were two sources of finding in this research. The first, was finding from the test and the second was from the field note. Firstly, the researcher will explain the finding from the test. 


\section{The Finding of the Test}

The first test conducted by the researcher was pre-test. Pre-test was done by the researcher in order to know the students' reading comprehension before giving the treatment. There were 31 students joined this pre-test. Then, the result of the test can be seen in the table below.

\section{Table 2 Students' Pre-test Score}

\begin{tabular}{|c|c|c|c|}
\hline No & Students' Name & Pre-test Score & Marking Quality \\
\hline 1 & AMD & 42.5 & $\mathrm{E}$ \\
\hline 2 & A & 0.8 & $\mathrm{E}$ \\
\hline 3 & AM & 52 & $\mathrm{D}$ \\
\hline 4 & $\mathrm{CC}$ & 84 & A- \\
\hline 5 & DG & 88 & $\mathrm{~A}$ \\
\hline 6 & ES & 64 & $\mathrm{C}$ \\
\hline 7 & $\mathrm{E}$ & 48 & $\mathrm{D}$ \\
\hline 8 & EA & 60 & $\mathrm{C}$ \\
\hline 9 & $\mathrm{~F}$ & 56 & $\mathrm{D}$ \\
\hline 10 & $\mathrm{~F}$ & 56 & $\mathrm{D}$ \\
\hline 11 & $\mathrm{~F}$ & 40 & $E$ \\
\hline 12 & FDMN & 56 & $\mathrm{D}$ \\
\hline 13 & FH & 56 & $\mathrm{D}$ \\
\hline 14 & $\mathrm{IO}$ & 84 & A- \\
\hline 15 & IJ & 60 & $\mathrm{C}$ \\
\hline 16 & $\mathrm{JC}$ & 88 & $\mathrm{~A}$ \\
\hline 17 & $\mathrm{~K}$ & 72 & B- \\
\hline 18 & LJA & 56 & $\mathrm{D}$ \\
\hline 19 & MID & 80 & $\mathrm{~B}+$ \\
\hline 20 & $\mathrm{R}$ & 68 & $\mathrm{C}+$ \\
\hline 21 & RA & 92 & $\mathrm{~A}$ \\
\hline 22 & $\mathrm{R}$ & 60 & $\mathrm{C}$ \\
\hline 23 & $\mathrm{RS}$ & 76 & $\mathrm{~B}$ \\
\hline 24 & SF & 60 & $\mathrm{C}$ \\
\hline 25 & SM & 64 & $\mathrm{C}$ \\
\hline 26 & $\mathrm{~S}$ & 60 & $\mathrm{C}$ \\
\hline 27 & $\mathrm{~V}$ & 72 & B- \\
\hline 28 & VS & 84 & A- \\
\hline 29 & WR & 56 & $\mathrm{D}$ \\
\hline 30 & YML & 72 & B- \\
\hline \multirow[t]{2}{*}{31} & YDS & 68 & $\mathrm{C}+$ \\
\hline & Mean Score & 64 & $\mathbf{C}$ \\
\hline
\end{tabular}


Based on table 2, it can be seen that there are only 3 students get score in A category, they are 2 students get 88 and 1 student get 92.3 students get score in Acategory that is 84,1 student get score in $\mathrm{B}+$ category that is 80,3 students get score in B- category that is 72,2 students get score in $\mathrm{C}+$ category that is 68,8 students get score in $\mathrm{C}$ category, they are 5 students get 60 , and 3 students get 64 . Moreover, there are 8 students get score in D category, there is 1 students get 52,1 student get 48 , and 6 students get 56 . The last is 3 students get score in E category, there is 1 student get $42.5,1$ student get $0.8,1$ student get 40 . The mean score of the pre-test is only 64 that is categorized as C. Therefore, it can be concluded that the students' reading comprehension is low.

The next test conducted by the researcher was progress-test 1 . Progress-test 1 was done by the researcher in order to know the progress of the students' reading comprehension after giving the treatment in the first cycle. There were 31 students joined this progress-test 1 . Then, the result of the progress-test can be seen in the table below.

Table 3 Students' First Progress-test Score

\begin{tabular}{clcc}
\hline No & Students' Name & First Progress-test Score & Marking Quality \\
\hline 1 & AMD & 65 & $\mathrm{C}+$ \\
\hline 2 & A & 45 & $\mathrm{D}$ \\
\hline 3 & AM & 67 & $\mathrm{C}+$ \\
\hline 4 & CC & 88 & $\mathrm{~A}$ \\
\hline 5 & DG & 77 & $\mathrm{~B}+$ \\
\hline 6 & ES & 67 & $\mathrm{C}+$ \\
\hline 7 & E & 45 & $\mathrm{D}$ \\
\hline 8 & EA & 75 & $\mathrm{~B}$ \\
\hline 9 & F & 78 & $\mathrm{~B}+$ \\
\hline 10 & F & 65 & $\mathrm{C}+$ \\
\hline 11 & F & 76 & $\mathrm{~B}$ \\
\hline 12 & FDMN & 75 & $\mathrm{~B}$ \\
\hline 13 & FH & 69 & $\mathrm{~B}-$ \\
\hline 14 & IO & 76 & $\mathrm{~B}$ \\
\hline 15 & IJ & 63 & $\mathrm{C}$ \\
\hline 16 & JC & 76 & $\mathrm{~B}$ \\
\hline 17 & K & 75 & $\mathrm{~B}$ \\
\hline 18 & LJA & 78 & $\mathrm{~B}+$ \\
\hline 19 & MID & 82 & $\mathrm{~B}+$ \\
\hline 20 & R & 78 & $\mathrm{~B}+$
\end{tabular}




\begin{tabular}{llcc}
\hline 21 & RA & 80 & $\mathrm{~B}+$ \\
\hline 22 & R & 67 & $\mathrm{C}+$ \\
\hline 23 & RS & 73 & $\mathrm{~B}$ \\
\hline 24 & SF & 67 & $\mathrm{C}+$ \\
\hline 25 & SM & 71 & $\mathrm{~B}-$ \\
\hline 26 & S & 67 & $\mathrm{C}+$ \\
\hline 27 & V & 92 & $\mathrm{~A}$ \\
\hline 28 & VS & 84 & $\mathrm{~A}-$ \\
\hline 29 & WR & 63 & $\mathrm{C}$ \\
\hline 30 & YML & 71 & $\mathrm{~B}-$ \\
\hline 31 & YDS & 65 & $\mathrm{C}+$ \\
\hline & Mean Score & $\mathbf{7 1 . 6}$ & B-
\end{tabular}

Based on table 3, it can be seen that there are 2 students get score in A category, there is 1 student get 88 and 1 student get 92.1 student get score in Acategory that is 84.6 students get score in B+ category, there is 1 student get 77,3 students get 78, 1 student get 80 , and 1 student get 82 . Next, there are 7 students get score in B category, there is 1 student get 73,3 students get 75,3 students get 76 . Then, 3 students get score in B- category, there is 1 student get 69 and 2 students get 71.8 students get score in $\mathrm{C}+$ category, there are 3 students get 65,5 students get 67. Moreover, there are 2 students get score in $\mathrm{C}$ category that consist of 2 students get 63 . There are 2 students get score in D category they are 2 students get 45. The mean score of the progress-test 1 is 71.6 that is categorized as B-. Therefore, it can be concluded that the students' reading comprehension is still low.

The last test conducted by the researcher was progress-test 2 . Progress-test 2 was done by the researcher in order to know the development of the students' reading comprehension in the second cycle. There were 29 students joined this progress-test. The result of the progress-test 2 can be seen in the table below.

Table 4 Students' Second Progress-test Score

\begin{tabular}{llcc} 
No & Students' Name & $\begin{array}{c}\text { Second Progress-test } \\
\text { Score }\end{array}$ & $\begin{array}{c}\text { Marking } \\
\text { Quality }\end{array}$ \\
\hline 1 & AMD & 80 & B+ \\
\hline 2 & A & 76 & B \\
\hline 3 & AM & 84 & A- \\
\hline 4 & CC & 92 & A \\
\hline 5 & DG & 84 & A- \\
\hline
\end{tabular}




\begin{tabular}{llcc}
6 & ES & 92 & A \\
\hline 7 & E & 76 & B \\
\hline 8 & EA & 88 & A \\
\hline 9 & F & 76 & B \\
\hline 10 & F & 92 & A \\
\hline 11 & F & 96 & A \\
\hline 12 & FDMN & 72 & A- \\
\hline 13 & FH & 84 & A- \\
\hline 14 & IO & 84 & A- \\
\hline 15 & IJ & 84 & B \\
\hline 16 & JC & 76 & - \\
\hline 17 & K & - & B \\
\hline 18 & LJA & 76 & A- \\
\hline 19 & MID & 84 & A \\
\hline 20 & R & 88 & A \\
\hline 21 & RA & 88 & A \\
\hline 22 & R & 88 & B \\
\hline 23 & RS & 76 & A \\
\hline 24 & SF & 88 & B+ \\
\hline 25 & SM & 80 & A- \\
\hline 26 & S & 84 & A \\
\hline 27 & V & 88 & B+ \\
\hline 28 & VS & 80 & - \\
\hline 29 & WR & - & B \\
\hline 30 & YML & 76 & B \\
\hline 31 & YDS & 88 & \\
\hline & Mean Score & $\mathbf{8 3 . 4}$ & \\
\hline & & & \\
\hline
\end{tabular}

Based on table 4, it can be seen that there are 10 students get score in A category, they are 6 students get 88 and 2 students get 92 and 1 student get 96 . Then, there are 7 students get 84 score that is categorized as A-. 3 students get 80 score that is categorized as B+. Next, there are 7 students get 76 score that is categorized in B. Last, 1 student get 72 score that is categorized in B-. The mean score of the progress-test 2 is 83.4 that is categorized as $\mathrm{B}+$. Therefore, it can be concluded that the students' reading comprehension score has increased and achieved the target score.

\section{Finding of the Field Note}

The finding of the field note in this research consisted of the finding of field note in the first cycle and the finding of the field note in the second cycle. 


\section{First Cycle}

After conducting pre-test and analyzing the pre-test score, the researcher began the first cycle. The first cycle consists of 4 stages, they were planning, acting, observing and reflecting. In the $1^{\text {st }}$ cycle, the researcher made planning for her teaching-learning process by preparing the learning material, the learning media, the reading comprehension exercises, field note and progress-test. In the stage of acting, the researcher applied the planning that has been arranged. She delivered the learning material to the students that was structural analysis. In this stage, she taught what is structural analysis, the function of structural analysis, structural analysis using root words, structural analysis using prefixes, and structural analysis using suffixes. Then, she gave students structural analysis exercise. In this stage, the researcher did it in 1 meeting that consist of 150 minutes. After giving the learning material, teaching structural analysis and giving structural analysis exercise to students, the researcher gave progress-test to students in the next meeting. In the stage of observing, the researcher observed the learning process by using field note. Based on her observation, she found that some students still get confuse about structural analysis. Some students cannot finish the exercise of structural analysis since they still confuse about it. Then, during the progress test, the researcher observed and found that some students look stress and tired while they were doing the test, some students were sleepy and some students tried to ask the answer to friend beside their. In addition, some students cannot finish the test based on the time given by the researcher. After finishing the stage of planning, acting, and observing, the researcher did reflection. Based on the reflection, the researcher decided that she has to explain again the structural analysis to the students clearer and more detail since there were some students still confuse about structural analysis. Next, based on the researcher observation during the progresstest which found that some students tried to ask the answer of the test to friend beside them, the researcher decided to add more space between one student to other student in the next progress-test. Then, based on the score of the progress-test that has not achieved the target yet that was only 71.6, the researcher decided to do the next cycle that is second cycle. 


\section{Second Cycle}

After conducting the first cycle and analyzing the score of the progress-test of the first cycle, the researcher began the second cycle. The second cycle consists of 4 procedures, they were planning, acting, observing and reflecting. In the second cycle, the researcher made planning for her teaching-learning process by preparing the learning material, the learning media, the reading comprehension exercises, field note and progress-test of second cycle. In the stage of acting, the researcher applied the planning that has been arranged. She explained the learning material to the students again because some students still confuse about structural analysis. In this stage, she explained again what is structural analysis, the function of structural analysis, structural analysis using root words, structural analysis using prefixes, and structural analysis using suffixes clearer and gave more examples. After explaining the structural analysis, she gave the students structural analysis exercise. In this stage, the researcher did it in 1 meeting that consist of 150 minutes. After explaining structural analysis and giving structural analysis exercise to students, the researcher gave progress-test of second cycle to students in the next meeting. In the stage of observing in the second cycle, the researcher also observed the learning process by using field note. Based on her observation, she found that students get better understanding about structural analysis. Some students can finish the exercise of structural analysis based on the time given by the researcher that was 1 hour. Then, the researcher also gave progress-test in the second cycle in the next meeting. The time given to students to finish the test is 90 minutes. During the second progresstest, the researcher observed and found that students more relax in doing the test. None student tried to ask friend for answer. After finishing the stage of planning, acting, and observing in the second cycle, the researcher did reflection. Based on the reflection, the researcher decided to finish the research since the target score has achieved that was 83.4.

\section{Discussion}

Based on the finding of the test, the researcher found that before the treatment given by the researcher and at the first cycle, the students' reading comprehension was still low because the result of their pre-test score was only 3 
students got score in A category, they were 2 students got 88 and 1 student got 92 . Then, only 3 students got score in A- category that was 84, only 1 student got score in $\mathrm{B}+$ category that was 80 . Moreover, 3 students got score in B- category that was 72, 2 students got score in $\mathrm{C}+$ category that was 68,8 students got score in $\mathrm{C}$ category, they were 5 students got 60 , and 3 students got 64 . Furthermore, there were 8 students got score in D category, there was 1 students got 52, 1 student got 48, and 6 students got 56. The last is 3 students got score in E category, there was 1 student got 42.5, 1 student got $0.8,1$ student got 40 and the mean score of the pretest was only 64 that was categories as $\mathrm{C}$.

Then, the result of the students' first progress-test score also showed the same fact that was the students' reading comprehension was still low because the mean score was only 71.6. There were only 2 students got score in A category, there was 1 student got 88 and 1 student got 92 . 1 student got score in A-category that was 84.6 students got score in B+ category, there was 1 student got 77, 3 students got 78, 1 student got 80 , and 1 student got 82 . Next, there were 7 students got score in B category, there was 1 student got 73, 3 students got 75, 3 students got 76 . Then, 3 students got score in B- category, there was 1 student got 69 and 2 students got 71.8 students got score in C+ category, there were 3 students got 65,5 students got 67. Moreover, there were 2 students got score in $\mathrm{C}$ category that consist of 2 students got 63 . There were 2 students got score in D category they were 2 students got 45. Therefore, it can be concluded that the students' reading comprehension in the first cycle was still low.

In line with the finding of the field note in the first cycle that the researcher found some students still got confuse about structural analysis. Some students could not finish the exercise of structural analysis since they still confuse about it. Then, during the progress test, some students looked stress and tired while they were doing the test, some students were sleepy, some students tried to ask the answer to friend beside them and some students could not finish the test by the time given by the researcher.

Have a difference of the first cycle, in the second cycle, the students' reading comprehension had improved and achieve the target score since the mean score of 
the second progress-test was 83.4 that was categorized as $\mathrm{B}+$. There were 10 students get score in A category, they were 6 students got 88 and 2 students got 92 and 1 student got 96 . Then, there were 7 students got 84 score that was categorized as A-. 3 students got 80 score that was categorized as B+. Next, there were 7 students got 76 score that was categorized in B. Last, only 1 student got 72 score that was categorized in B-. Therefore, it can be concluded that the students' reading comprehension score has increased and achieved the target score in the second cycle.

The same as the finding of the field note in the second cycle, in the second cycle, the researcher found that students got better understanding about structural analysis. Some students could finish the exercise of structural analysis by the time given by the researcher that was 1 hour. Then, during the second progress test, the researcher observed and found that students more relax in doing the test and none student tried to ask friend for answer.

\section{CONCLUSION}

Based on the finding and discussion in previous chapter, the researcher could draw some conclusions, they are: (1) Structural analysis was positively improved the reading comprehension of $\mathrm{E}$ class second semester students of Business English and Management Concentration Tonggak Equator Polytechnic in academic year 2017-2018 within two cycles, they were first cycle and second cycle. (2) The significance of the use of structural analysis in improving the reading comprehension of E class second semester students of Business English and Management Concentration Tonggak Equator Polytechnic in academic year 20172018 could be seen based on the test given they were 64 for the pre-test, 71.6 for the first progress-test and 83.4 for the second progress-test, and from the field note, that the students looked tired, sleepy, looked for answer from student beside them and could not finish the test by the time given by the researcher in the first cycle but have significant progress in the second cycle that the students looked more relax in doing the test and could finish the test by the time given by the researcher. Then, there are several things the researcher would like to suggest, they are: (1) In order to make all of the students understand the definition of structural analysis, the parts 
of the word and how the parts are combined, the researcher suggests the next researcher to explain the definition of structural analysis, the parts of the word and how the parts are combined again and again. (2) In order to help the students understand and always remember the parts of the word and how the parts are combined, the researcher suggests the next researcher to often give structural analysis exercises.

\section{BIBLIOGRAPHY}

Burns, A. (2010). Doing Action Research in English Language Teaching: A guide for Practitioners: New York: Routledge Taylor \& Francis Group.

. (1999). Collaborative Action Research for English Language Teachers. Cambridge: Cambridge University Press.

Hancock, Ophelia H. Reading Skills for College Students. New Jersey: PrenticeHall.

Linge, M. K. (2000). Reading Tutor (How to Help Your First or Second Grader Become Great at Reading). New York: Learning Express.

Nuttal, C. (1982). Teaching Reading Skills in a Foreign Language (12 ${ }^{\text {th }}$ Ed). Heinemann: Educational Books Press.

Patel, M.F. and Jain (2008). English Language Teaching (Methods, Tools and Techniques). Vaishali Nagar: Sunrise Publishers and Distributors.

Silberstein, S. (1994). Technique and Resources in Teaching Reading. New York: Oxford University Press. 